\title{
REFLECTIVE CAREER DIALOGUES
}

\section{F. Meijers}

Department of Business, Finance and Marketing

The Hague University of Applied Sciences

The Hague, Netherlands

e-mail: frans@fransmeijers.nl

\section{R. Lengelle}

Faculty of Humanities and Social Sciences

Athabasca University

Athabasca, Canada

e-mail: reineke@tic.ab.ca

\section{ABSTRACT}

Due to the challenges produced by the individualisation of society and the flexibilisation of employment relationships, universities are increasingly investing in career guidance. Managers, however, have little or no vision regarding guidance and counselling. In this article we make a plea for an approach in which students are enabled to develop a career identity (i.e. a story about the meaning of their lives) as a basis for self-directedness. Such stories emerge during a dialogue about felt experiences. Evidence is given that such dialogues are to a large degree absent in educational contexts. Universities are to a large extent 'disembodied' places where almost no room exists for emotions and felt experiences. Therefore, a work/learning environment is needed within universities that enables 'passionate self-directedness'. A short outline for creating such an environment is given.

Keywords: Self-direction, reflective dialogue, career identity, career stories, career learning environment

\section{INTRODUCTION}

In most post-industrial societies individuals are faced with a growing pressure to make choices, while at the same time, due to flexibilisation of employment relationships (Arthur, Inkson and Pringle 1999) and individualisation within society (Beck 1994), less and less direction is provided. Careers are to a large extent unpredictable (Arthur, Khapova and Wilderom 2005), forcing career scientist to formulate 'a chaos theory of careers' (Pryor and Bright 2011). In the midst of this chaos, the individual is expected to demonstrate more and more self-directedness based on a well-developed identity, both on the labour market (Savickas 2000; Kuijpers and Scheerens 2006) and in society as a whole (Giddens 1991). The growing importance of identity 
(or personality as it is often referred to) as an important production factor in a service economy (Hochschild 1983; Sennett 1998) becomes clear when one looks at vacancy descriptions. Thirty years ago, 100 per cent of the vacancy descriptions for jobs requiring higher education in the Netherlands, for instance, clearly noted what the required education was, 50 per cent described the necessary work experience and 20 per cent outlined the preferred interest for the job. Nowadays, all vacancy descriptions in the Netherlands contain general competencies, of which most relate to employability and personal development in terms of flexibility, learning ability, and reflective and pro-active behaviour. Even for jobs in for-profit organizations, qualities such as passion, ambition and self-development are listed under the requirements (Kuijpers 2007; see also Hillage, Regan, Dickson and McLoughlin 2002; Lafer 2004; Schulz 2008). Whereas, previously, the emphasis was on technical skills (Cedefop 2010; Grugulis and Vincent 2009; Leckey and McGuigan 1997), in post-industrial societies employers are looking for graduates with so-called 21st century skills. The core of these skills can be characterised by the concept of 'passionate self-directedness'.

As a result of the developments outlined above, universities in the European Union are increasingly investing in career guidance to promote $21^{\text {st }}$ century skills among their students (Company 2009). They cannot leave this task to the public or private sector for several reasons. First, universities are funded by governments and are therefore expected to prepare their students adequately for life as well as for the labour market (Wagner 2010; Trilling and Fadel 2009). Second, organisations in the private and public sector often lack the knowledge and the motivation to guide young people on their career journeys (OECD 2004, 2010; Johnson 2009). Third, research shows that students are seldom able to make good choices without guidance (career counselling) (Dijksterhuis and Nordgren 2006; Dijksterhuis, Bos, Nordgren and Van Baaren 2006). At the same time, it is clear that the guidance provided is still a informed by the traditional 'trait and factor' approach that doesn't enable students to become more self-directed based on a well-developed identity (Hughes, Meijers and Kuijpers 2015). Managers responsible for guidance have little or no vision regarding career guidance and counselling (Meijers 2008; Kuijpers and Meijers 2015). In part, the lack of a clear vision among managers - and the politicians behind them - is the result of a lack of consensus about what constitutes effective career guidance in educational contexts (Hughes, Meijers and Kuijpers 2015; Nusche et al. 2014).

\section{A STRONG CAREER-LEARNING ENVIRONMENT}

Universities in general embrace the idea of developing $21^{\text {st }}$ century skills without realising that 
such skills require a different learning environment and different teacher competencies than when the focus was on traditional theoretical and technical competencies (Payne 2000; Smith and Comyn 2004). Postmodern career counselling theories (f.i. Savickas 2002, 2013) are predicate don the belief that in order to develop a capacity for self-directedness, students need to develop a career identity, i.e. a coherent story about their lives that creates a sense of identity and direction (Meijers and Lengelle 2012, 2015). Schools should not give more (or even 'better') information to students in order to make an 'informed' decision (which in most cases is not well-informed at all; see Krieshok, Black and McKay 2009). Instead, they should help students develop their career-life story. Career stories emerge during a dialogue in which personal meaning is attached to concrete experiences regarding work (Lengelle et al. 2014, 2015). In order to facilitate and have such a dialogue, the thoughts and feelings of students with respect to their work experiences must be given a central place in the conversation (Philip 2001; Bardick et al. 2006). Students and their teachers, however, do not seem to participate in a career dialogue willingly. For teachers to expand their capacity for conducting career dialogues, their professional identities must evolve and this creates personal uncertainty (Kuijpers and Meijers 2015). Students are rarely motivated to participate in reflective activities about their careers when these are prescribed as part of the curriculum (Mittendorff 2010). Due to the highly theoretical nature of school curriculum, they fail to see the connection between mandated 'reflective' activities and 'real life' and, therefore, regard reflection with the help of portfolios or personal development plans as largely useless (Mittendorff et al. 2008).

\section{THE IMPORTANCE OF ATTAINING CAREER COMPETENCIES}

Kuijpers and Scheerens (2006) identify five distinctive career competencies: capacity reflection (observation of capabilities that are important for one's career), motivation reflection (observation of wishes and values that are important for one's own career), work exploration (researching work and job possibilities), career directedness (making thoughtful decisions and taking actions that allow work and learning to correspond with one's capabilities and motivation and challenges at work), and finally, networking (building and maintaining contacts focused on career development). Research by Kuijpers, Meijers and Gundy (2011) makes it clear that career stories develop in part as career competencies are being acquired. However, attainment of career competencies also result from the learning process that shapes career identity. A career identity, in other words, is the result of experiential learning: reflection and action must go hand in hand.

In a large-scale empirical study among students in Dutch universities, Kuijpers and 
Meijers (2012) showed that a learning environment that stimulated real-life experiences with work and a dialogue about these experiences contributed most to the development and use of career competencies. Even when personality traits of students and their differing educational programs were taken into account, the characteristics of the learning environment influenced the degree to which (and the kind of) career competencies that were learned and used. More particularly, the career dialogue in schools and the conversation students have in the workplace proved to be crucial. Both contributed to career reflection, career-forming (work exploration and career directedness), and networking. In actual fact, this dialogue was more strongly correlated with the development of career competencies than personality traits were. In groups in which a career method or a so-called personal-development plan was used, students reported reflecting more on their careers. In addition, more reflection took place in groups in which students, who threatened to drop out, were engaged in a dialogue. This didn't mean, however, that these students gave more direction (or participated in 'career-forming' with regards) to their careers. Students who did more work placements, reported that they indeed gave more direction to their careers and they also networked more frequently. That said, more traditional forms of career guidance, such as a conversation with the guidance counselor and career guidance tests, did not noticeably encourage students to use career competencies either. It was also found that concrete experiences in the workplace and assignments in school should be used to promote reflection among students and to help them orient themselves with regards to their career futures. Conversations about these experiences were crucial in helping students acquire career competencies.

Based on their findings, Kuijpers and Meijers (2012) and Meijers, Kuijpers and Gundy (2013) concluded that a career-oriented learning environment (in other words, a learning environment that stimulates the application of career competencies and the development of a career identity) is an environment in which students can acquire real-life work experience and at the same time can participate in a career-oriented dialogue about their learning experiences with work. Such a learning environment differs in many ways from a traditional learning environment in that it is: (a) not primarily focused on information transfer but oriented towards obtaining actual work experiences; (b) not focused on a monologue (from teacher to student) but on a dialogue between teacher and student; (c) not focused on interventions at certain institutionally determined decision-making moments but on continued guidance; (d) not solely aimed at cognition but takes emotion into consideration as well; and (e) not geared towards a standard-learning route but focused on the creation of more choices and the promotion of mutual participation. 


\section{CAREER DIALOGUE}

As a consequence of the dominant school culture, it is difficult to achieve an actual career dialogue in the current education system. Quinn (1991) argues that in organizations that remain stable over a long period of time, a culture develops that is attractive to personality types who value output, control, and management (for instance, a fixed instead of a growth mindset; see Dweck 2000; Dweck and Molden 2007). In full-time education in particular, the culture with respect to the interaction between students and teachers hardly changed in the last decades. Everything was and is focused on the efficient transfer of established knowledge facilitated by an established curriculum. The teacher still is the central figure, seen as enthusiastically transferring knowledge to students from his or her precise and well-defined area of expertise. Expectedly, Hensel (2010) found that university teachers in the Netherlands scored higher than average on 'neuroticism' and lower than average on 'openness', both variables of the Big Five Inventory (De Fruyt 1996). Unsurprisingly, therefore, that even today, schools rarely offer room for the development or expression of student narratives (Winters et al. 2009). Likewise, because educational culture is still largely monological, most teachers are quite uncertain about their abilities to help students develop a career story (Kuijpers, Meijers and Winters 2010; Harlaar and Meijers 2014). It should be acknowledged that teachers feel uncertain in this area because the effectiveness of a dialogical career approach largely depends - as in all forms of counselling (Wampold 2001; Cooper 2008) - on the trust counsellor have in their chosen approach.

In a series of studies, Winters (2012) and Winters et al. (2009, 2013) used Dialogical Self Theory (Hermans and Hermans-Konopka 2010) as a framework for understanding and analyzing how conversations about placements foster career construction. The starting point of the Dialogical Self Theory is that the formation of an identity is dialogical in nature because the Self is actually a kind of 'polyphonic novel' or combination of various voices ('I-positions') embodied in one person (Hermans and Kempen 1993). Although expressed by one person, the polyphonic novel is spoken by many 'sub-personalities' or I-positions. 'As different voices these characters exchange information about their respective $M e$ 's and their world, resulting in a complex, narratively structured self' (Hermans, Kempen and Van Loon 1992, 28-29). The dialogical self is not static and is inherently transformed by either the exchanges amongst Ipositions (the internal dialogue with ourselves) or by exchanges with other individuals (the external dialogue). An identity, therefore, is co-constructed, socially situated, and performed in interactions. It is a practice of positioning, whereby 'master narratives’ (Davies and Harré 1990) and discourses - as LaPointe (2010, 2) describes: 'position individuals and construct their 
identities in the interaction between narrator and audience .... Positioning refers to the process through which people can adopt, resist and offer the subject positions made available in discourses and master narratives.' It is worth noting that internal and external dialogue are only separate in the way we conceptualize them; how we interpret our lives is very much a 'psychosocial' phenomenon (Gross 2006). People are motivated to engage in internal and external dialogues because each dialogue satisfies one of two core human needs: a sense of autonomy and control and on the other hand being part of a wider community (Brewer 1991; Leonardelli, Pickett and Brewer 2010). To be happy we must feel in balance with ourselves and be connected with others.

From the perspective of the Dialogical Self Theory, the trajectory from real-life experiences to an appropriate career choice ideally starts with the formulation of an I-position, followed by the subsequent broadening of this I-position by means of a dialogue to other relevant I-positions, progress, via consecutive dialogical shifts, from these various I-positions to a meta-position, and from this meta-position to the formulation of a promoter-position. By ' $\mathrm{I}$ ' positions, we mean that a student is asked to enter a dialogue in a multi-voiced way experiences may be discussed in ambiguous and contradictory ways (e.g. I like working with seniors; I don't like working with them when they don't interact; I like working with them when we are both quiet). However, in order to turn dialogues into competencies and actions, an ability to witness the presence and influence of the various 'I' positions is needed as well. This is where a meta-position is valuable, as it allows the individual to view one's I-positions from a distance. In career learning this means that we are able to develop and express various perspectives and explore options without becoming 'married' to any one of them from the outset. The integrative understanding gained through a meta-position is intended to lead us to action or at the very least to the intention to act, while we remain aware of the complexity and changeability of our work environment and ourselves. The 'position' that is capable of taking action, with the intention to give a developmental impetus to future I-positions, is called a promoter position.

\section{CHARACTERISTICS OF A GOOD DIALOGUE}

Based on this dialogical-learning process, several characteristics of a good dialogue can be distinguished. First, the teacher should not speak about or at the students as happens frequently in an educational system still primarily focused on semantic (reproductive) learning; teachers must really speak with their students for meaning-oriented learning to occur. This seems like common sense, but research on career guidance shows this rarely happens in Dutch education (Winters et al. 2009, 2013). Dialogues must be about experiences relevant to the student and 
this becomes apparent when a student expresses emotion words. As a matter of fact, the presence of emotion words frequently indicate that a so-called boundary experience (Meijers and Lengelle 2012) is being referred to. Boundary experiences often refer to life themes, which in turn - when given a voice - form the foundation of self-directedness (Savickas et al. 2010). The emotions present shouldn't be ignored. Instead good use has to be made of what is salient for students which is identified based on emotions. Allowing emotions to do their work is only possible under particular conditions as Doorewaard suggests (2000, 44-45). First, emotions have to be valued; in other words, all those involved in a social interaction should be grateful that emotions exist. Second, emotions should be treated with caution. They show the often extremely powerful motives for the behaviour of individuals. When an emotion is ignored or even denied, it can turn against the organization, which allows a type of denial to occur and this may often result in the paralysis of not only the individual itself, but also of its environment. Third, emotions demand concentrated attention. Many people feel uncomfortable when someone nearby shows some emotional involvement. The tendency to quickly move on to something else is often strong and frequently the default (for this happening in career conversations see Winters et al. 2012). However, if emotions are ever to become a functional part of the learning process whereby a career identity may be constructed, then attention has to be paid to them. One should not try to suppress these emotions, but rather to use them to illuminate the message that they are carrying (see also Ashforth and Humphrey 1995, 97).

However, as Rand $(1984,72)$ says, 'rationalization is a process of not perceiving reality, but of attempting to make reality fit one's emotions'. Humans are much more apt to reach for ways of avoiding change and displaying the symptoms of holding on described by Baker and Stauth (2003) in the acronym 'VERB' - victimization, entitlement, rescue, and blame. To overcome this natural tendency, a student must be helped to talk about what happened as concretely as possible. This can be done in the form of small stories (see Doerr 2004). Once a small story is on the table, one should invite the student to broaden and deepen it. Broadening is helping the student to look for similar occurrences in the present, while deepening it is looking for similar events that have happened in the past. Both broadening and deepening help the student to describe which happenings led them to the same reaction and thus uncover their life themes. By putting these stories side by side, the student is able - through a process of comparing - to develop analogies and on that basis to name personal constructs. A good dialogue gives students the opportunity to compare; it is imperative that students are guided to make such comparisons.

Youths as well as adults are seldom able to go through this process without help. Human 
brains are not well equipped to deal with insecurity; as soon as a boundary experience occurs flight, fight, and fleeing responses are usually inevitable (Meijers and Lengelle 2012). When individuals show this triggered response, teachers usually have the tendency to ask 'why' questions in an attempt to promote more rational behaviour. However, a 'why' question can usually only be answered once the learning process has been completed. The trigger is an indication that learning is necessary and not that an explanation is forthcoming. It is important, therefore, not to ask 'why' questions. The teacher should instead make room for the naming of emotions - a small story does not only describe what happened but also invites the client to speak about feelings associated with the story. Research on expressive writing aimed at wellbeing has shown that this combination of telling what happened along with the emotions felt is indeed the winning combination in creating a beneficial narrative (Pennebaker 2011). Not only does an emotion show one what is meaningful to a student, but naming an emotion is the first step in helping someone step into the observer position. Teachers must also be aware of their own natural tendency to reduce insecurity by trying to speak for the student. The essential part of helping someone with identity learning is to go in search of the right words with the student, which becomes evident when the student says, 'Yes, this expresses what I really feel'.

\section{DO SCHOOLS HAVE ROOM FOR A GOOD DIALOGUE?}

There are doubts as to whether such career dialogues are actually stimulated in schools. Winters et al. (2009) looked at conversations about placements in Dutch secondary vocational education. The research showed that it is not the student who is at the heart of the conversation, but the curriculum and furthermore that mentors in school and from work placement talk mostly to (65\%) and about (21\%) students, and hardly ever with (9\%) them. The students respond to their teachers and their mentors from practice, but this does not mean that they can take part in the conversation actively and direct it to reflect on their personal learning goals. Little opportunity is given to students to express what they think of their experiences in the work place, let alone about what they have learned or wanted to learn from having been there. Training conversations are almost completely aimed at the evaluation of the student and on transferring expert opinions from teacher and mentor to students.

Recent research by Harlaar-Oostveen and Meijers (2014) and Assen et al. (in press, due during 2017) at Dutch universities shows that a divide exists between what Schön (1983, 64) calls the espoused theory and the theory in use. Harlaar-Oostveen and Meijers (2014) researched how teachers perceived the quality of the reflective dialogue during career conversations with students. This research shows that while teachers regard reflection and 
dialogue as very important during the actual conversation about a student's work placement, such reflection doesn't happen enough. It is notable too that most teachers have no clear or agreed-upon picture of what should be understood as a 'good dialogue'. Teachers do say that dialogue is important and that more of it should take place. At the same time they seem to fear asking the deeper questions during a conversation about work experience. How the work placement has affected the student or which emotions were felt is considered important but little is asked about it. Teachers seem uncertain about digging deeper. What is meant by concepts such as 'evaluating' and 'reflecting' is not clear to teachers and these concepts are used interchangeably. Finally, there is no consensus among teachers about the goal of the conversation about the work placement: everyone formulates a different goal about what such a conversation should achieve.

Assen (in press, due during 2017) found that university instructors had a clear preference for problem-oriented approaches in their teaching. However, in everyday practice traditional curriculum-based interventions were applied. Semi-structured interviews done with 83 teachers showed that this inconsistency was caused by the way in which problem-oriented learning was imbedded in the curriculum, the confidence that teachers had in the ability of students of students to be self-directed and, last but not least, with the confidence teachers had in their own teaching abilities. Just as Harlaar-Oostveen and Meijers (2014), Assen noticed that many teachers feel very unsure about whether they can function adequately in a dialogical context.

Winters et al. (2013) furthermore explored the quality of career conversations in three culturally different contexts within vocational education: conversations between teachers and 15-year old students in pre-vocational education ('prevocational group'), conversations between teachers, workplace mentors and 18-19 year old students in secondary vocational education ('secondary vocational group') and conversations between workplace mentors and 18-19 year old students in secondary vocational education ('workplace group'). Results showed that the average conversation does have potential with regards to constructing a career identity. Positioning (i.e. formulating an I-, meta- or promoter position) does happen and is done mainly by students themselves. In pre-vocational education, more I-positions are formulated than in secondary vocational education and more than in the workplace, probably due to the existing culture of carefulness (i.e. much attention is paid to the well-being of each individual student). In the workplace, more meta- and promoter positions are formulated than in both other contexts, probably due to a business-like culture in which every individual is held responsible for the success of the group. In secondary vocational education, the conversations are longest, but they offer even less room for positioning than the less-standardized and shorter 
inquiries about how students' placements went in pre-vocational education. This is probably due to the fact that 65 per cent of all students in secondary vocational education enter the labour market immediately after completing their course of studies. This is one of the reasons why the quality of secondary vocational education is under close surveillance by the Department of Education (Hughes, Meijers and Kuijpers, 2015). Employers and politicians force schools to use standardized evaluative procedures, which leave little room for the narratives of both students and teachers (for a description of the same tendency in the USA, see Nichols and Berliner 2007). A dialogue was not dominant in any of the contexts studied. In other words, when a student 'positions him/herself', teacher and mentor strategies are rarely directed at stimulating the broadening of those positions, let alone focused on the formulation of meta- and promoter positions.

Winters et al. (2013) were especially interested in the response of teachers to student positioning. In their analysis of video-taped conversations between teachers and students about placements, they found four different strategies: ignoring the I-position (ignoring), repositioning by talking on behalf of the student (re-positioning), broadening the $I$-position without conclusion (broadening), and dialogue in the direction of the formulation of a promoterposition (promoting). The evidence showed that the three studied contexts show strong similarities when it comes to using strategies 'ignoring' and 'promoting'. In an average conversation, a formulated position is ignored twice (to 2,5 times for the workplace and secondary vocational group), while per conversation an $I$-position stimulates a dialogue resulting in the formulation of a promoter-position less than once $(0,5$ times for the prevocational and secondary vocational group). The strategy 're-positioning' happens twice per average conversation (once per conversation in the prevocational group and three times per conversation in the workplace and secondary vocational group). When it comes to 'promoting' as a strategy, an average conversation shows this dynamic twice (the workplace group stands out with an average of 3,5 times per conversation as compared to the prevocational and secondary vocational groups). The conclusion is obvious: positioning is done by the students themselves and teachers/mentors respond most often with non-dialogical strategies (i.e. ignoring and re-positioning).

\section{CONCLUSION}

Universities are to a large extent 'disembodied' places where almost no room exists for emotions and felt experiences. The absence of dialogue and the subsequent lack of control by students over their own learning processes, results in students' lack of intrinsic motivation with 
regards to what is taught. Most students in fact have a purely instrumental relationship with the curriculum and their teachers (Holt 1995; Franciosi 2004; Nichols and Berliner 2007; Gatto 2009). Many students see no other choice but to reproduce 'the logic of the system' which means they continue to count on the promise that investment in education (i.e. a certification) alone will ultimately pay off. Teachers, in turn, find themselves, as Hargreaves (2003) shows, caught in a conflicting triangle of interests and imperatives. This triangle requires teachers to be (a) catalysts of the promises of opportunity and prosperity of the knowledge society; (b) counterpoints to the threats posed by the knowledge society to community, security, environment, and the public good; and (c) casualties of the standardization imposed by imperatives of the knowledge society.

In order to create a cultural shift within education that enables 'passionate selfdirectedness' among students, teachers and managers require work/learning environments that have to meet three conditions.

First, they have to be practice based: the learning process of teachers and middlemanagers must be based on questions and problems that arise from actual innovative practices that are intentional and are a response to concrete problems that result based on those practices. In addition, the learning environment must be clearly structured, which means that teachers and middle managers should not have too many innovations occurring simultaneously. In practice, this means that the number of innovations running should pared down and/or innovations should be more integrated and convergent. More consideration should be given to learning ability or readiness (in addition to learning that is desired) of teachers (in terms of their capacity to carry out and carry on with such an innovation load).

Second, they have to promote dialogical interactions: dealing with concrete problems will only lead to changes in the professional identity of teachers and middle-managers (and with that to truly innovative practices) if a conversation between all parties concerned occurs about the personal and societal meaning of one's work. The kind of dialogue that is needed, is described by Shotter $(1993,20)$ as 'a socially constructed myriad of spontaneous, responsive, practical, unselfconscious, but contested interactions', a conversation that is 'quite the opposite of the apparent representation of dialogue as converging upon a single ultimate "Truth"'. As will be clear from Shotter's quote, dialogue is something completely different than a discussion. A dialogue means to show and accept uncertainty (see Meijers and Lengelle 2012).

And, third, work/learning environments have to foster cooperation and consensus on the basis of a clear and strategic management vision: initiating and keeping such a dialogue going demands transformational leadership (Geijsel and Meijers 2005; Geijsel, Meijers and 
Wardekker 2007). This type of leadership simultaneously provides direction based on the strategic vision, but also creates space for teachers and middle managers to set out their own tactics to achieve desired goals. Additionally, the space described can only be created when upper management keep a dialogue going about the concrete work experiences of teachers and middle-managers.

\section{REFERENCES}

Ashforth, B. E. and R. H. Humphrey. 1995. Emotion in the workplace: A reappraisal. Journal of Management 17(1): 99-120.

Assen, H., F. Meijers, H. Otting and R. Poell. In press, due 2017. Explaining discrepancies between tutor beliefs and tutor interventions in a problem-based learning environment. Teaching and Teacher Education (in press)

Arthur, M. B., K. Inkson and J. Pringle. 1999. The new careers - Individual action and economic change. London: Sage.

Arthur, M. B., S. N. Khapova and C. P. M. Wilderom. 2005. Career success in a boundaryless career world. Journal of Organizational Behaviour 26(2): 177-202.

Baker, D. and C. Stauth. 2003. What happy people know. New York: St. Martin’s Griffin.

Bardick, A. D., K. B. Bernes, K. C. Magnusson and K. S. Witko. 2006. Junior high school students' career plans for the future. A Canadian perspective. Journal of Career Development 32(2): 250271.

Beck, U. 1994. The reinvention of politics - towards a theory of reflexive modernisation. In Reflexive Modernisation, ed. U. Beck, A. Giddens and S. Lash, 1-56. Cambridge, UK: Polity Press.

Brewer, M. B. 1991. The social self: On being the same and different at the same time. Personality and Social Psychology Bulletin 17(6): 475-482.

Cedefop. 2010. The skill matching challenge: Analyzing skill mismatch and policy implications. Luxemburg: European Centre for the Development of Vocational Training.

Company, F. J. 2009. Vocational guidance and career counselling in the European Union: Origins and recent trends. In International Handbook of education for the changing world of work. Bridging academic and vocational learning, ed. R. Maclean and D. N. Wilson, 2313-2329. New York: Springer.

Cooper, M. 2008. Essential research findings in counselling and psychotherapy - the facts are friendly. London: Sage.

De Fruyt, F. 1996. Personal and vocational interest: Relationship between the Five Factor model of personality and Holland's Riasec typology. Doctoral dissertation. Ghent, Belgium: University of Ghent.

Davies, B. and R. Harré. 1990. Positioning: The discursive production of selves. Journal for the Theory of Social Behaviour 20(1): 43-63.

Dijksterhuis, A. and L. F. Nordgren. 2006. A theory of unconscious thought. Perspectives on Psychological Science 2: 95-109.

Dijksterhuis, A., M. W. Bos, L. F. Nordgren and R. B. van Baaren. 2006. On making the right choice. The deliberation-without-attention-effect. Science 311(5763): 1005-1007.

Doerr, M. 2004. Currere and the environmental autobiography: A phenomenological approach to the teaching of ecology. New York: Peter Lang.

Doorewaard, H. 2000. De andere organisatie... en wat heeft de liefde er nou mee te maken? (The other organisation ... what has love got to do with it?) Utrecht: Lemma. 
Dweck, C. S. 2000. Self-theories: Their role in motivation, personality, and development. Philadelphia: Psychology Press.

Dweck, C. S. and D. C. Molden. 2007. Self-theories: Their impact on competence motivation and acquisition. In Handbook of competence and motivation, ed. A. J. Elliot and C. S. Dweck, 31-51. New York, NY: Guilford Press.

Franciosi, R. J. 2004. The rise and fall of American public schools: The political economy of public education in the twentieth century. Westport, CT: Praeger.

Gatto, J. T. 2009. Weapons of mass instruction. Gabriola Island, Canada: New Society Publishers.

Geijsel, F. and F. Meijers. 2005. Identity learning: The core process of educational change. Educational Studies 31(4): 419-430.

Geijsel, F., F. Meijers and W. Wardekker. 2007. Leading the process of reculturing: Roles and actions of school leaders. The Australian Educational Researcher 34(2): 124-150.

Giddens, A. 1991. Modernity and self-identity - the self and society in the late modern age. London: Polity Press.

Gross, D. 2006. The secret history of emotion: From Aristotle's rhetoric to modern brain science. Chicago and London: The University of Chicago Press.

Grugulis, I. and S. Vincent. 2009. Whose skill is it anyway? Soft skills and polarization. Work, Employment and Society 23(6): 597-615.

Hargreaves, A. 2003. Teaching in the knowledge society: Education in the age of insecurity. New York: Teachers College Press.

Harlaar-Oostveen, M. and F. Meijers. 2014. Zijn stagegesprekken in het hbo reflectief en dialogisch? Tijdschrift voor Hoger Onderwijs 32(4): 245-256.

Hensel, R. 2010. The sixth sense in professional development. A study o the role of personality, attitudes and feedback concerning professional development. Doctoral dissertation. Enschede, Netherlands: Twente University.

Hermans, H. J. M., H. J. G. Kempen and R. J. P. van Loon. 1992. The dialogical self: Beyond individualism and rationalism. American Psychologist 47: 23-33.

Hermans, H. and H. Kempen. 1993. The dialogical self - Meaning as movement. San Diego, CA: Academic Press.

Hermans, H. J. M. and A. Hermans-Konopka. 2010. Dialogical self theory. Positioning and counterpositioning in a globalizing society. Cambridge, UK: Cambridge University Press.

Hillage, J., J. Regan, J. Dickson and K. McLoughlin. 2002. Employers Skill Survey 2002. Research Report 372. Nottingham, UK: DfES.

Hochschild, A. 1983. The managed heart: Commercialisation of human feelings. Berkeley: University of California Press.

Holt, J. 1995. How children fail (rev. ed.). Reading, MA: Perseus Books.

Hughes, D., F. Meijers and M. Kuijpers. 2015. Testing times: Careers market policies and practices in England and the Netherlands. British Journal of Guidance and Counselling 43: 183-201.

Johnson, D. 2009. Bridging the learning divide: A study into adult learning and peer mediation in the workplace. In International Handbook of education for the changing world of work. Bridging academic and vocational learning, ed. R. Maclean and D. N. Wilson, 219-234. New York: Springer.

Krieshok, T. S., M. D. Black and R. A. McKay. 2009. Career decision making: The limits of rationality and the abundance of non-conscious processes. Journal of Vocational Behavior 76: 275-290.

Kuijpers, M. 2007. Loopbaanontwikkeling in het beroepsonderwijs [Career learning in vocational education]. The Hague, the Netherlands: The Hague University of Applied Sciences.

Kuijpers, M. A. C. T. and J. Scheerens. 2006. Career competencies for the modern career. Journal of Career Development 32: 303-319. 
Kuijpers, M., F. Meijers and A. Winters. 2010. Loopbaanleren van start tot finish. Eindverslag van de kwantitatieve metingen in 2007 en 2010 in het project 'Loopbaanleren in competentiegericht onderwijs' in ROC de Leijgraaf. Oss/Veghel, the Netherlands: De Leijgraaf

Kuijpers, M., F. Meijers and C. Gundy. 2011. The relationship between learning environment and career competencies of students in vocational education. Journal of Vocational Behavior 78(1): 21-30.

Kuijpers, M. and F. Meijers. 2012. Learning for now or later? Career competencies among students in higher vocational education in the Netherlands. Studies in Higher Education 37(3): 449-467.

Kuijpers, M. and F. Meijers. 2015. Professionalising teachers in career dialogue: An effect study. British Journal of Guidance and Counselling. DOI: 10.1080/03069885.2015.1121203.

Lafer, G. 2004. What is 'skill'? Training for discipline in the low-wage labour market. In The skills that matter, ed. C. Warhurst, I. Grugulis and E. Keep, 112-129. Basingstoke: Palgrave Macmillan.

LaPointe, K. 2010. Narrating career, positioning identity: Career identity as a narrative practice. Journal of Vocational Behavior 77(1): 1-9.

Leckey, J. and M. McGuigan. 1997. Right tracks - wrong rails: The development of generic skills in higher education. Research in Higher Education 38(3): 365-378.

Lengelle, R., F. Meijers, R. Poell and M. Post. 2014. Career Writing: Creative, expressive and reflective approaches to narrative identity formation in students in higher education. Journal of Vocational Behavior 85(2): 75-84.

Lengelle, R., F. Meijers, R. Poell, F. Geijsel and M. Post. 2015. Career writing as a dialogue about work experience: A recipe for luck readiness? International Journal for Educational and Vocational Guidance 13(1): 47-66.

Lengelle, R. and F. Meijers. 2015. Playwright meets career coach: Writing dialogues to promote awareness and self-direction. In New horizons in career counselling: Turning challenges into opportunity, ed. K. Maree and A. Di Fabio, 315-327. Boston, MA: Sense Publishers.

Leonardelli, G. J., C. L. Pickett and M. B. Brewer. 2010. Optimal distinctiveness theory: A framework for social identity, social cognition, and intergroup relations. Advances in Experimental Social Psychology 43(1): 63-113.

Meijers, F. 2008. Mentoring in Dutch vocational education: An unfulfilled promise. British Journal of Guidance and Counselling 36(3): 235-252.

Meijers, F. and R. Lengelle. 2012. Narratives at work: The development of career identity. British Journal of Guidance and Counselling 40(2): 157-177.

Meijers, F. and R. Lengelle. 2015. Career learning: Qualitative career assessment as a learning process in the construction of a narrative identity. In Career assessment: Qualitative approaches, ed. M. McMahon and M. Watson, 41-49. Boston, MA: Sense Publishers.

Meijers, F., M. Kuijpers and C. Gundy. 2013. How do career competencies relate to career identity, motivation and quality of choice in Dutch prevocational and secondary vocational education? International Journal for Vocational and Educational Guidance 13(1): 47-66.

Mittendorff, K. 2010. Career conversations in senior secondary vocational education. Doctoral dissertation. Eindhoven, the Netherlands: TU Eindhoven.

Mittendorff, K., W. Jochems, F. Meijers and P. den Brok. 2008. Differences and similarities in the use of the portfolio and personal development plan for career guidance in various vocational schools in The Netherlands. Journal of Vocational Education and Training 60: 75-91.

Nichols, S. L. and D. C. Berliner. 2007. Collateral damage: How high stakes testing corrupts America's schools. Cambridge, MA: Harvard University Press.

Nusche, D., H. Braun, G. Halász and P. Santiago. 2014. OECD Reviews of evaluation and assessment in education: Netherlands. Main conclusions. Paris: OECD.

Organisation for Economic Co-operation and Development. 2004. Career guidance and public policy: Bridging the gap. Paris: OECD Publishing. 
Organisation for Economic Co-operation and Development 2010. Are the new millennium learners making the grade? Technology use and educational performance in PISA 2006. Paris: OECD Publishing.

Payne, J. 2000. The unbearable lightness of skill: the changing meaning of skill in UK policy discourses and some implications for education and training. Journal of Education Policy 15(3): 353-369.

Pennebaker, J. 2011. The secret life of pronouns. New York: Bloomsbury Press.

Philip, K. 2001. Mentoring: Pitfalls and potential for young people. Youth and Policy 71: 1-15.

Pryor, R. G. L. and J. E. H. Bright. 2011. The chaos theory of careers. New York and London: Routledge.

Quinn, R. E. 1991. Beyond rational management. Mastering the paradoxes and competing demands of high performance. San Francisco, CA: Jossey-Bass.

Rand, A. 1984. Philosophy: Who needs it. New York: Signet.

Savickas, M. L. 2000. Career development and public policy: The role of values, theory, and research. In Making waves: Career development and public policy, ed. B. Hiebert and L. Bezanson, 48-59. Ottawa: Canadian Career Development Foundation.

Savickas, M. 2002. Career construction: A developmental theory of vocational behaviour. In Career choice and development, ed. D. A. Brown, 149-205. San Francisco, CA: Jossey-Bass.

Savickas, M. L., L. Nota, J. Rossier, J. P. Dauwalder, M. E. Duarte, J. Guichard, S. Soresi, R. van Esbroeck and A. E. M. van Vianen. 2010. Life designing: A paradigm for career construction in the 21th century. Journal of Vocational Behavior 75(3): 239-250.

Savickas, M. 2013. Career construction theory and practice. In Career development and counseling: Putting theory and research to work, ed. R. W. Lent and S. D. Brown, 147-183. $2^{\text {nd }}$ edition. Hoboken, NJ: Wiley.

Schön, D. 1983. The reflective practitioner: How professionals think in action. New York: Basic Books.

Schulz, B. 2008. The importance of soft skills: Education beyond academic knowledge. NAWA Journal of Language and Communication 2: 146-154.

Sennett, R. 1998. The corrosion of character. The personal consequences of work in the new capitalism. London: Norton.

Shotter, J. 1993. Cultural politics of everyday life: Social constructionism, rhetoric, and knowing of the third kind (CP). Toronto, Canada: Toronto University Press.

Smith, E. and P. Comyn. 2004. The development of employability skills in novice workers through employment. Generic skills in vocational education and training: Research readings, 95-108 http://files.eric.ed.gov/fulltext/ED493988.pdf\#page=95 (accessed 30 January 2014).

Trilling, B. and C. Fadel. 2009. 21st Century skills: Learning for life in our times. San Francisco, CA: Jossey-Bass.

Wagner, T. 2010. The global achievement gap. New York, NY: Basic Books.

Wampold, B. E. 2001. The great psychotherapy debate: Models, methods, and findings. Mahwah, NJ: Lawrence Erlbaum.

Winters, A., F. Meijers, M. Kuijpers and H. Baert. 2009. What are vocational training conversations about? Analysis of vocational training conversations in Dutch vocational education from a career learning perspective. Journal of Vocational Education and Training 61(3): 247-266.

Winters, A., F. Meijers, R. Lengelle and H. Baert. 2012. The self in career learning: An evolving dialogue. In Handbook of dialogical self theory, ed. H. J. M. Hermans and T. Gieser, 454-469. Cambridge, UK: Cambridge University Press.

Winters, A., F. Meijers, M. Harlaar, A. Strik, M. Kuijpers and H. Baert. 2013. The narrative quality of career conversations in vocational education. Journal of Constructivist Psychology 26(1): 115126. 